Kapata Arkeologi, 13(1), 95-108

ISSN (cetak): 1858-4101

ISSN (elektronik): 2503-0876

http://kapata-arkeologi.kemdikbud.go.id

\title{
EKSPANSI KEKUASAAN ISLAM KESULTANAN TERNATE DI PESISIR TIMUR HALMAHERA UTARA
}

\author{
The Expansion of Islamic Power of Ternate Sultanate \\ in the East Coastal of North Halmahera
}

\author{
Wuri Handoko \\ Balai Arkeologi Maluku - Indonesia \\ J1. Namalatu-Latuhalat Ambon 97118 \\ wuri_balarambon@yahoo.com
}

Naskah diterima: 04/03/2017; direvisi: 22/03 - 04/06/2017; disetujui: 05/06/2017

Publikasi ejurnal: 25/07/2017

\begin{abstract}
North Halmahera is an expansion area of Ternate Sultanate, a Muslim state in eastern Indonesia. This study focuses on archaeological evidence to explain the process and development of the influence of Islamic Ternate Sultanate in that region. Through archaeological surveys, literature studies and interviews, gathered evidence on the influence of Islam in the region, especially its relation to the political power and economic factor of the Ternate Sultanate, as the center of Islamic power in North Maluku. The result shows that the east coast of North Halmahera, including Tobelo, Galela and Kao, is an expansion area of Ternate's Islamic rule that developed since the 16th century $A D$, even the evidence of the region under Ternate's rule can still be found today.
\end{abstract}

Keywords: expansion, Islam, archeology, history, Ternate, North Halmahera

\begin{abstract}
Abstrak
Halmahera Utara merupakan wilayah kekuasaan Kesultanan Ternate, sebuah kerajaan Islam di Indonesia bagian timur. Kajian ini menitikberatkan pada bukti-bukti arkeologis untuk menjelaskan proses dan perkembangan pengaruh Islam Kesultanan Ternate di wilayah tersebut. Melalui survei arkeologi, studi literatur dan wawancara, dikumpulkan bukti-bukti tentang pengaruh Islam di wilayah tersebut, terutama hubungannya dengan faktor politik kekuasaan dan ekonomi Kesultanan Ternate, sebagai pusat kekuasaan Islam di Maluku Utara. Hasil penelitian menunjukkan bahwa wilayah pesisir timur Halmahera Utara, meliputi Tobelo, Galela dan Kao, merupakan wilayah ekspansi kekuasaan Islam Ternate yang berkembang sejak abad $16 \mathrm{M}$, bahkan bukti-bukti wilayah tersebut dibawah kekuasaan Ternate masih dapat dijumpai hingga sekarang.
\end{abstract}

Kata kunci: ekspansi, Islam, arkeologi, sejarah, Ternate, Halmahera Utara

\section{PENDAHULUAN}

Wilayah Maluku Utara, diwakili oleh Ternate dan Tidore dikenal sebagai pusat penghasil cengkeh, sebuah hasil dari pengembangan cengkeh yang berjalan cepat pada akhir abad XV dan XVI. Selain itu Ternate dan Tidore juga dikenal sebagai pusatnya Maluku, bahkan menurut Andaya (2015) di luar wilayah Ternate dan Tidore disebutnya sebagai dunia pinggiran Maluku (Andaya, 2015:95). Demikian pula, dalam konteks penulisan sejarah tentang Islam, sejauh ini dalam berbagai literatur, Kesutanan Ternate tampil menjadi penguasa Islam yang paling dominan di Maluku Utara, yang kekuasaannya menyebar di berbagai wilayah pulau-pulau sekitarnya, bahkan hingga ke wilayah bagian selatan Kepulauan Maluku, yang saat ini termasuk dalam wilayah administratif Provinsi Maluku antara lain meliputi Pulau Seram, Buru, Ambon, Lease dan wilayah-wilayah lainnya (Putuhena, 2001: 62- 
66; Leirissa, 2001: 8). Kesultanan Ternate menjadi pusat kekusaan Islam yang bertahan hingga sekarang.

Meskipun Kesultanan Ternate, sebagai wilayah pusat peradaban dan kekuasaan Islam, namun menyangkut proses perkembangan dan penyebaran pengaruh Islam ke daerah lainnya, merupakan kajian yang kompleks. Hal ini karena perluasan kekuasaan Islam dari Kesultanan Ternate, dilakukan dalam mobilitas tinggi, dan bersaing pengaruh dengan pihak kolonial. Persaingan pengaruh kekuasaan dari Kesultanan Ternate dengan pihak kolonial, terutama dalam perebutan geopolitik dan geoekonomi, mempengaruhi tumbuh dan berkembangnya budaya Islam, sekaligus menjadi pemicu atas faktor perbedaan karakteristik budaya Islam antara Kesultanan Ternate dengan wilayah lainnya (Handoko, 2008: 3-5, 11; Handoko, 2009: 19).

Dalam konteks penulisan ini, wilayah Halmahera Utara, dari studi historiografi, merupakan salah satu wilayah pengaruh Islam Kesultanan Ternate. Adanya bukti-bukti pengaruh budaya, adopsi dan konversi Islam masyarakat dan bukti-bukti ekspansi kekuasaan
Islam, dan berbagai bentuk dinamikanya di wilayah-wilayah yang secara geopolitik dianggap strategis maupun wilayah yang dianggap jauh secara geopolitik dan sosial ekonomi dari pusat kekuasaan dan zona perdagangan Islam, di wilayah Maluku Utara.

Secara geopolitik, dalam catatan sejarah yang ada, wilayah-wilayah penelitian ini beberapa diantaranya dianggap tidak cukup siginifikan berpengaruh terhadap perkembangan sosial, ekonomi dan politik masa pengaruh Islam. Wilayah-wilayah di Halmahera Utara, seperti Tobelo, Galela, Moro dan Kao serta Loloda memiliki hubungan histroris dengan Ternate, baik politik maupun ekonomi (Amal, 2010: 212-215; Naping, 2013: 82-91; Willard, Hana, \& Alwi, Des, 1996: 84-89). Meski demikian, berdasarkan bukti-bukti arkeologi yang ditemukan, menunjukkan bahwa wilayahwilayah itu memiliki peran penting dalam proses penyebaran kekuasaan Kesultanan Ternate.

Berbagai penulisan sejarah Islam di wilayah Kepulauan Maluku, diantaranya meliputi kajian tentang proses penyebaran Islam, daerah asal penyebar, proses penerimaan hingga perkembangannya, dan secara keseluruhannya

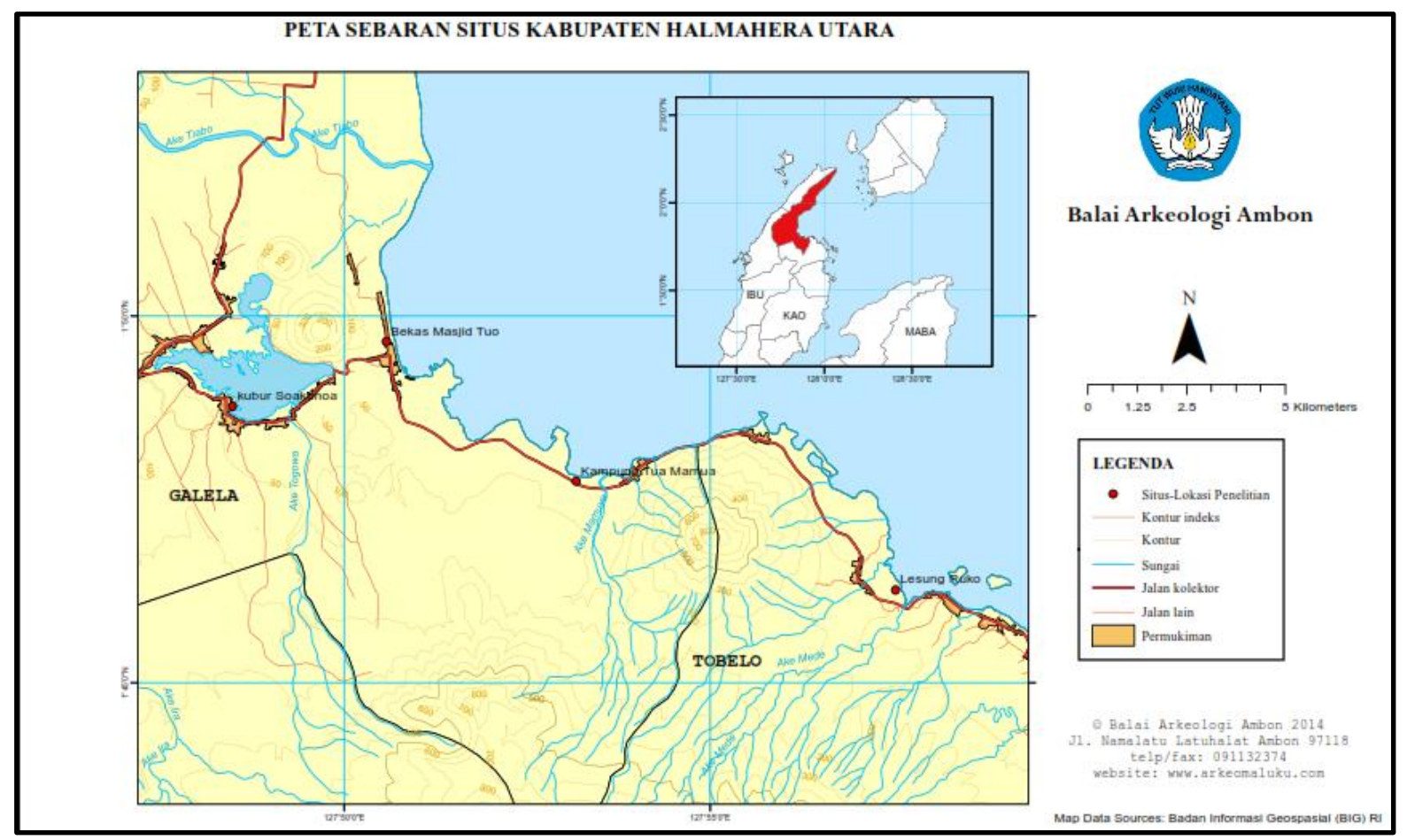

Gambar 1. Peta keletakan situs-situs di pesisir timur Halmahera Utara

(Sumber: Tim Penelitian, 2014) 
itu selalu dihubungkan dengan Kesultanan Ternate, sebagai daerah pusat peradaban Islam. Meski demikian, hingga saat ini, teori tentang jalur Islamisasi di Kepulauan Maluku (Provinsi Maluku dan Maluku Utara) masih terus dikaji. Beberapa pendapat yang mengemukakan teori masuknya Islam di wilayah ini diantaranya oleh Mailoa (1977), bahwa Islam berkembang di Maluku Utara diduga berasal dari Malaka, Kalimantan, atau Jawa. Prodjokusumo (1991), mengemukakan bahwa Banjar dan Giri atau Gresik cukup besar pengaruhnya dalam sosialisasi Islam di Maluku Utara, sebelum terjadi arus balik, yakni penyebaran Islam dari Maluku ke arah barat yakni Buton dan daerah lain di Sulawesi Selatan (Mailoa dan Prodjokusumo dalam (Ambary, 1998: 153). Meski demikian, penting dicatat, Islam dianggap masuk ke wilayah Maluku pada sekitar abad 14, seperti yang terkandung dalam tradisi lisan yang menyebutkan Raja Ternate XII akrab dengan pedagang Islam (Ambary, 1996: 6).

Berdasarkan hal tersebut, Ambary mengemukakan kemungkinan lain bahwa Islam masuk melalui jalan Cina Selatan dan tidak melalui Selat Malaka. Pada abad 15, Ternate merupakan pusat kekuatan utama penghasil rempah-rempah. Diantara kerajaan besar lainnya, seperti Kesultanan Tidore, Jailolo dan Bacan,Ternate menjadi pusat untuk memimpin aliansi empat kerjaan tersebut (Ambary, 1998: 153-154). Selain itu pengaruh Islam yang langsung dari negara asal penyebar Islam juga terdapat bukti-bukti yang kuat, seperti berkembangnya koloni-koloni Arab di Ternate. Komponen kota Ternate, menempatkan kampung-kampung Arab dalam tata ruang kota yang bertahan hingga sekarang, disamping peran penyebar Islam dari komunitas Melayu dan Jawa (Handoko, 2015: 129-130).

Penelitian ini adalah untuk menelusuri pengaruh dan perkembangan Islam dari Kesultanan Ternate di wilayah Halmahera Utara, berdasarkan bukti-bukti arkeologi. Tema tersebut diangkat dalam penelitian ini, karena penelitian arkeologi sejarah, terutama berkaitan dengan Islam di wilayah pesisir timur Halmahera Utara, masih minim. Sejauh ini penelitian arkeologi di wilayah ini fokus pada tema prasejarah yang beberapa diantaranya terutama di lakukan oleh peneliti asing. Selain itu, bahkan penelitian sejarah Halmahera Utara kaitannya dengan sejarah kerajaan Islam di Maluku Utara juga masih sangat terbatas.

Kesultanan Ternate yang berkedudukan di Pulau Ternate, dengan wilayah geografis yang kecil itu mampu menjadi penguasa Islam di wilayah Kepulauan Maluku. Kesultanan Ternate, adalah satu dari empat kerajaan besar yang berkembang menjadi kesultanan Islam, bahkan menjadi kesultanan yang memimpin empat aliansi kekuasaan Islam lainnya yakni Kesultanan Tidore, Bacan dan Jilolo. Isu penting dari penelitian ini adalah tentang faktor penguasaan wilayah yang kaya sumberdaya, merupakan aspek yang sangat penting dan menentukan sehingga Kesultanan Ternate dapat berkembang dan bertahan menjadi pusat kekuasaan Islam di Kepulauan Maluku.

Berdasarkan hal tersebut, rumusan masalah dalam penelitian ini dapat diuraikan sebagai berikut: pertama, bagaimana jejak arkeologi dan sejarah perkembangan Islam di wilayah Halmahera Utara? Kedua, bagaimana faktor yang melatarbelakangi Kesultanan Ternate, meluaskan pengaruh kekuasaan dan mengembangkan Islam di wilayah Halmahera Utara?

Tujuan penelitian ini dalam kerangka akademis mengacu pada tiga paradigma arkeologi yakni rekonstruksi sejarah kebudayaan, rekonstruksi tingkah laku manusia masa lampau dan di wilayah proses penggambaran budaya. Berdasarkan permasalahan penelitian, maka penelitian ini bertujuan untuk: pertama, menjelaskan perkembangan Islam wilayah-wilayah pengaruh Kesultanan Ternate. Dalam kerangka rekonstruksi sejarah kebudayaan, maka tujuan ini meliputi pada penjelasan tentang perkembangan awal Islam dan perkembangan agenda Islamisasi itu sendiri berdasarkan data arkeologi yang ditemukan maupun berdasakan analogi data sejarah. Kedua, Menjelaskan dinamika Islam hidup dan dianut masyarakat, tentang prosespenyebaran Islam dan karakteristisk Islam yang berkembang di masyarakat pada masa lampau. Penjelasan ini mencakup pula tentang kemungkinan adanya model pendekatan konversi Islam masyarakat baik melalui kelembagaan raja atau sultan, maupun pendekatan secara individual, latar politik yang berkembang dan motivasi ekonomi yang mempengaruhi proses penyebaran Islam di wilayah penelitian pada masa lampau. 
Islamisasi adalah tentang bagaimana Islam datang, kemudian diterima dan dipraktekkan oleh pemimpin politik dan sejumlah besar pengikut mereka. Mereka membangun bukti kronologi dan konteks budaya masyarakat yang banyak dipercaya oleh para sarjana tentang adanya ide-ide yang dibawa Islam ke wilayah Asia Tenggara. Dua pendekatan teoretis tentang model konversi menjadi dasar panduan. Satu mengusulkan topdown konversi, ketika para pemimpin politik mendorong konversi skala besar dari pengikut mereka, sedangkan yang lainnya mengusulkan bahwa Islamisasi adalah proses bottom-up konversi, yakni pemimpin politik melakukan konversi hanya jika cukup banyak rakyat mereka sudah Muslim. Dalam kerangka ini, telah terjadi perdebatan tentang peran politik Islam dan pendekatan sufi yang dianggap mudah diterima masyarakat dan lebih adaptif dengan sistem kepercayaan masyarakat Asia Tenggara yang ada sebelum mengenal Islam (Reid 1995: 333; Lape: 2000c: 830). Islamisasi tampaknya telah disertai peningkatan perdagangan maritim antara Pulau Asia Tenggara dan dunia muslim barat. Peningkatan perdagangan ini dipicu oleh permintaan yang muncul untuk rempah-rempah di Eropa abad pertengahan akhir dan penurunan aktivitas pedagang Cina akibat politik internal dan ketidakstabilan politik di sepanjang Jalur Sutra. Peluang pasar baru ini bertemu dengan pedagang maritim dari Timur Tengah dan Asia Selatan (Chaudhuri 1990; Glover 1990; Miksic et al. 1994 dalam Lape: 2000a: 48-55).

Penyebaran Islam, dalam berbagai sudut pandang, dilihat pula sebagai faktor integrasi, yakni menyatukan kekuatan-kekuatan dalam satu formasi politik dan sosial untuk melawan hegemoni kolonial pada masa itu. Hal ini karena antara pengaruh Islam dan kedatangan kolonial yang tidak terpaut jauh, mengakibatkan persaingan tidak hanya melibatkan kekuasaankekuaasaan Islam, namun juga pihak kolonial. Bagi banyak orang Maluku, Islam memberikan kerangka ideologis penting untuk melawan pengaruh budaya dan kontrol politik Eropa dan sebagai alat pemersatu dari entitas politik yang berbeda (Andaya 1993; Reid, 1993 dalam Lape, 2000c: 145). Islam adalah alat politik yang digunakan oleh para pemimpin untuk mengkonsolidasikan kekuasaan mereka dalam bentuk monarki yang sesuai dalam doktrin Islam dan melemahkan lawan mereka dalam usaha mengontrol perdagangan dan politik (Johns 1995; Reid 1995; Ricklefs 1979; Lape 2000c: 145).

Dalam sejarah Islam di wilayah Kepulauan Maluku, terdapat empat kerajaan besar yang disebut Moluko Kie Raha (Ternate, Tidore, Bacan, dan Jalilolo) sebagai pusat-pusat kekuasaan dan peradaban Islam. Wilayahwilayah ini kemudian memperlebar daerah kekuasaan dengan melakukan ekspansi ke wilayah lainnya. Pada banyak kasus, ekspansi kekuasaan dibarengi pula dengan perluasan jaringan perdagangan. Oleh karenanya wilayahwilayah ekspansi kekuasaan Islam, merupakan juga daerah perluasan zona perdagangan kerajaan-kerajaan Islam.

\section{METODE}

Lokasi penelitian berada di wilayahwilayah yang dianggap sebagai wilayah kekuasaan Ternate, di daratan Pulau Halmahera dan pulau-pulau di sekitar wilayah Ternate. Penentuan lokasi penelitian ini merujuk data pustaka sebelumnya tentang wilayah-wilayah ekspansi kekuasaan Ternate diantaranya adalah wilayah yang sekarang menjadi bagian administratif Kabupaten Halmahera Utara. Lokasi penelitian meliputi wilayah bekas Kerajaan Moro dan sekitarnya, meliputi kecamatan Kao, Tobelo dan Galela. Selain itu lokasi penelitian dikembangkan dari hasil wawancara.

Pengumpulan data melalui survei dan observasi. Penelitian ini menggunakan metode arkeologi (Willey dan Philips, 1958 dalam Deetz, 1967:17) yang pada tingkat observasinya dititikberatkan pada survei permukaan. Metode survei permukaan dan observasi dilakukan di wilayah-wilayah dari kekuasaan Ternate di pesisir timur Halmahera Utara berdasarkan hasil studi pustaka maupun wawancara.

Studi pustaka dengan mempelajari literatur tentang sejarah perkembangan wilayah Halmahera Utara. Selain itu juga dilakukan wawancara terbuka dengan informan-infoman kunci unuk mengetahui berbagai informasi sejarah setempat, toponim-toponim kuno dan sebagainya. Wawancara juga untuk menggali informasi tradisi lisan terkait dengan perkembangan Islam di wilayah penelitian. Analisis ragam dan sebaran data arkeologi dan interpretasi berdasarkan data arkeologi dan hasil catatan lapangan baik hasil wawancara, 
deskripsi tentang kondisi sosial masyarakat, lingkungan dan vegetasi, serta kemungkinan adanya data-data sekunder yang penting seperti peta kuno, naskah kuno dan sebagainya.

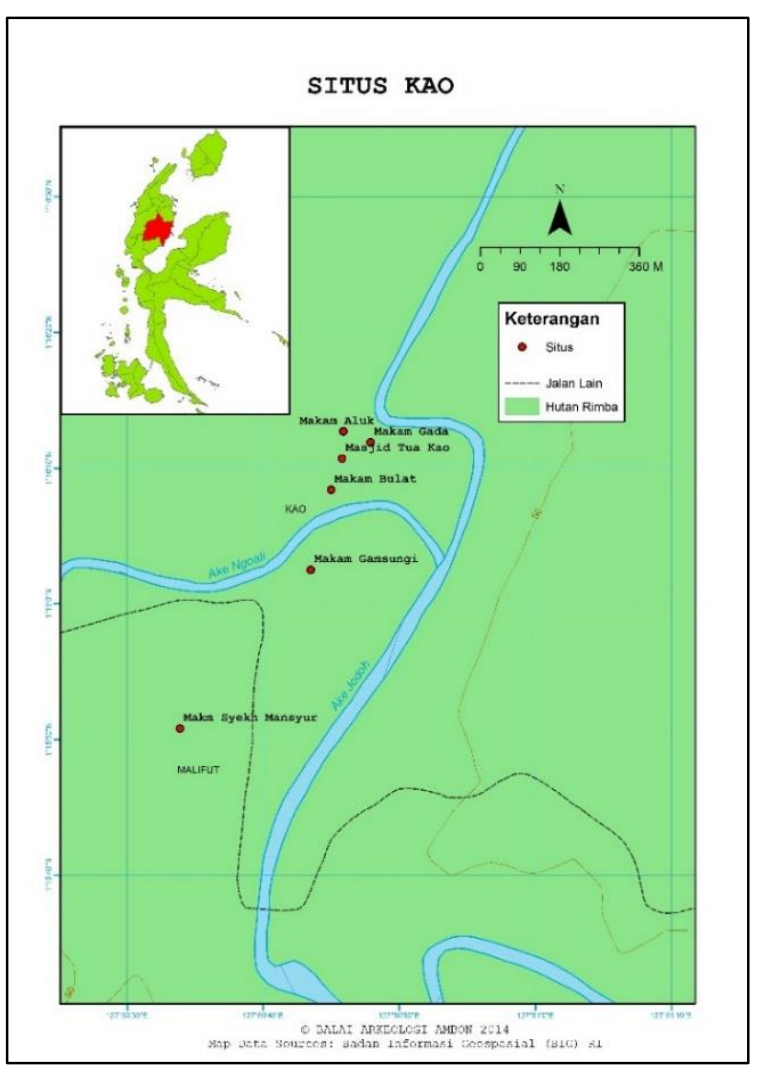

Gambar 2. Sebaran situs-situs arkeologi di kawasan situs Kampung tua Kao

(Sumber: Tim Penelitian, 2014)

\section{HASIL DAN PEMBAHASAN}

\section{Bukti Arkeologi Ekspansi Kekuasaan Islam Ternate}

Penelitian ini menjangkau di wilayah pesisir timur Halmahera Utara. Survei antara lain di wilayah kecamatan Galela, meliputi desa Galela, Soa Konora dan Pune. Kemudian di wilayah Kecamatan Tobelo, meliputi desa Ruko dan Mamuya, serta di wilayah Kecamatan Kao, yakni di Desa Kao. Dari keseluruhan survei, ditemukan indikasi-indikasi arkeologi yang potensial untuk menjelaskan perkembangan budaya dan sejarah masyarakat setempat. Dalam kerangka arkeologi Islam, hasil survei dapat memberi petunjuk tentang proses Islamisasi dan beberapa diantaranya secara faktual menunjukkan peran Ternate dalam proses perluasan Islam di wilayah itu. Selain itu, tampaknya Situs Kao yang paling banyak ditemukan data arkeologi, kemungkinan memberi petunjuk adanya pusat penyebaran Islam di wilayah Halmahera Utara, yang menempatkan peran sentral Kao dalam proses ekspansi Islam oleh Ternate (Tim Penelitian, 2014: 71-72, Handoko et.al., 2016: 112).

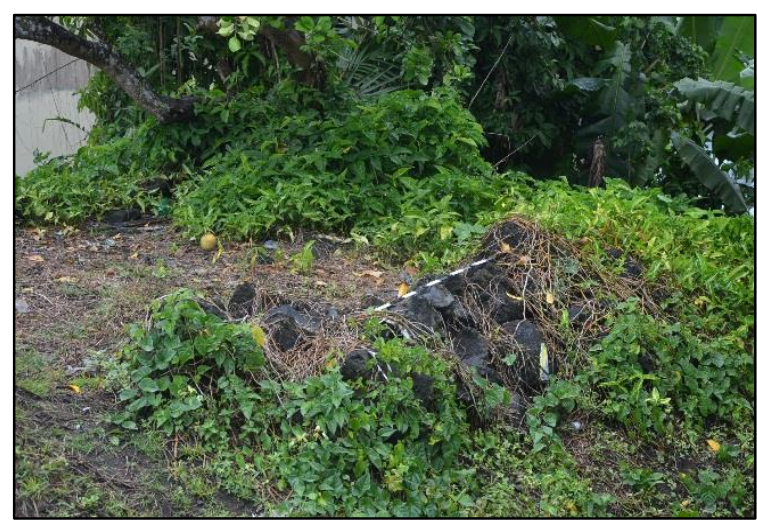

Gambar 3. Susunan batu, bekas masjid tua di situs desa Soakonora, di tepi danau Galela

(Sumber: Tim Penelitian, 2014)

Pada survei di wilayah Galela desa Soakonora, ditemukan bukti-bukti atau indikasi adanya bekas pemukiman di wilayah Danau Galela. Meskipun masih sebatas survei awal dengan jangkauan survei yang terbatas, ditemukan jejak adanya pemukiman lama yang mungkin hadir sejak masa Islam awal. Dalam tradisi tutur masyarakat dijelaskan bahwa Soakonora yang sekarang, merupakan pemukiman yang dibentuk oleh penganjur Islam yang sekaligus merupakan utusan Sultan Ternate, Jabir Syah. Dari hasil survei pada posisi di pinggir danau sebelah timur, ditemukan sebaran keramik.

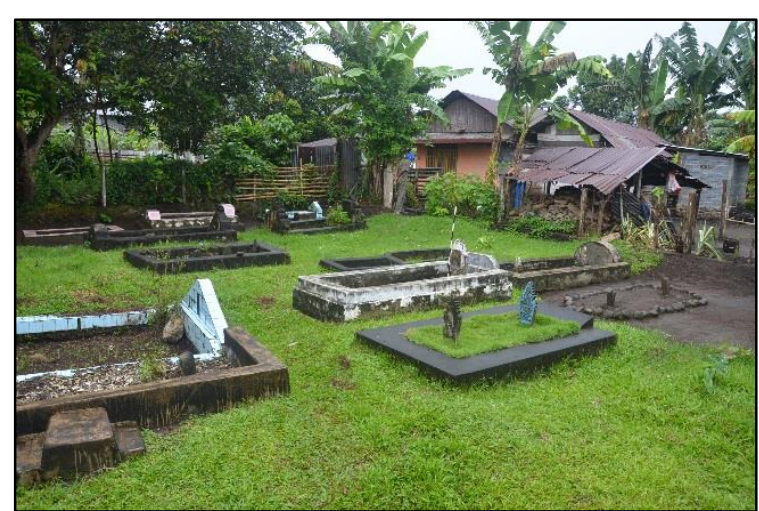

Gambar 4. Kompleks Makam Abdullah Geser atau Abdullah Joge bersama kerabat yang berada di tengah pemukiman di Desa Soakonora (Sumber: Tim Penelitian, 2014) 
Meskipun sebaran keramik dari pengamatan survei tidak begitu padat, namun cukup memberikan gambaran bahwa di wilayah tersebut difungsikan sebagai pemukiman. Selain itu keramik juga diperoleh dari koleksi penduduk. Pada bagian sebelah selatan danau, ditemukan adanya indikasi bekas bangunan, berupa susunan batu yang diduga sebagai bagian dari pondasi bangunan. Menurut informasi masyarakat, struktur batu tersebut merupakan bekas pondasi masjid lama. Menurut tradisi setempat, Soa Konora, pada masa lampau terbentuk dari gabungan dua negeri yang disebut Kampung Suku Ici dan kampong Suku Hate (Tim Penelitian, 2014).

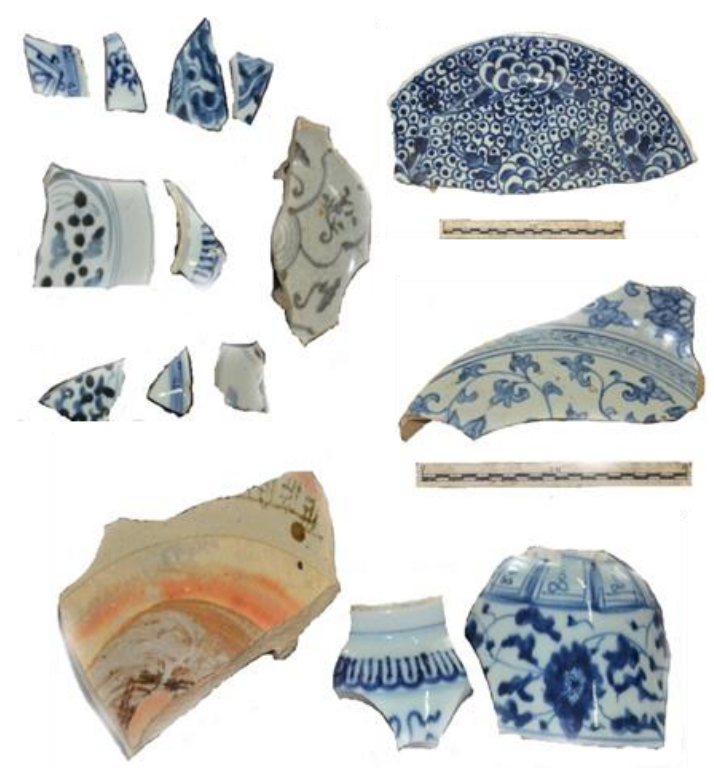

Gambar 5. Berbagai jenis keramik Situs Desa Pune (Sumber: Balai Arkeologi Ambon, 2014)

Ketika proses Islamisasi, dua kampung tersebut disatukan menjadi Soakonora, yang berarti dikumpulkan di tengah-tengah kampung. Dari tradisi tutur menyebutkan bahwa penggabungan dua kampung tersebut dilakukan oleh Sultan Ternate, Jabir Syah. Pada masa itu, diutuslah penyebar Islam oleh Sultan Jabir Syah seseorang dari wilayah setempat yang sebelumnya sudah diislamkan bernama Abdullah Geser atau Abdullah Joge. Sebutan penyebar Islam adalah Joguru. Soakonora terletak di sebelah timur laut Danau Galela. Menurut sumber lisan, proses pengislaman berakhir tahun 1914.

Situs Pune di daerah pesisir, dekat Pelabuhan lama Galela, ditemukan sebaran keramik yang cukup padat. Pada umumnya keramik berasal dari Dinasti Ming (16-17) dan Qing (18-19). Pada masa lampu hubungan niaga antara Pune dan Galela, merupakan satu kesatuan sebagai pusat niaga dan Islamisasi di Galela. Pune adalah salah satu desa yang terdekat dengan Galela, atau berbatasan langsung dengan Desa Galela. Dalam sejarah, meskipun Pune kurang disebut, namun pada masa kesultanan, Pune dianggap sebagai salah satu kota penting di wilayah Galela, sebagai wilayah niaga (Amal, 2010: 129). Dari hasil survei ditemukan sebaran keramik yang cukup padat, yang membuktikan bahwa daerah ini pada masa lampau merupakan salah satu pelabuhan penting pada masa ekspansi kekuasaan Ternate di wilayah Galela khususnya dan pesisir Halmahera Utara pada umumya.

Hasil survei di wilayah Soasiu, ibukota Kecamatan Galela, ditemukan bekas masjid kuno Soasiu, bekas pelabuhan lama, dan makam kuno Kapitan Lahamajojo, seorang sangaji (kapitang atau panglima perang) yang diperintahkan di wilayah Galela. Pada lokasi bekas masjid kuno sekarang, digunakan sebagai bangunan untuk rumah pengajian, masih terdapat bekas struktur pondasi, dan sumur tua yang masih dimanfaatkan. Masih terdapat sisasisa struktur bekas tangga naik.

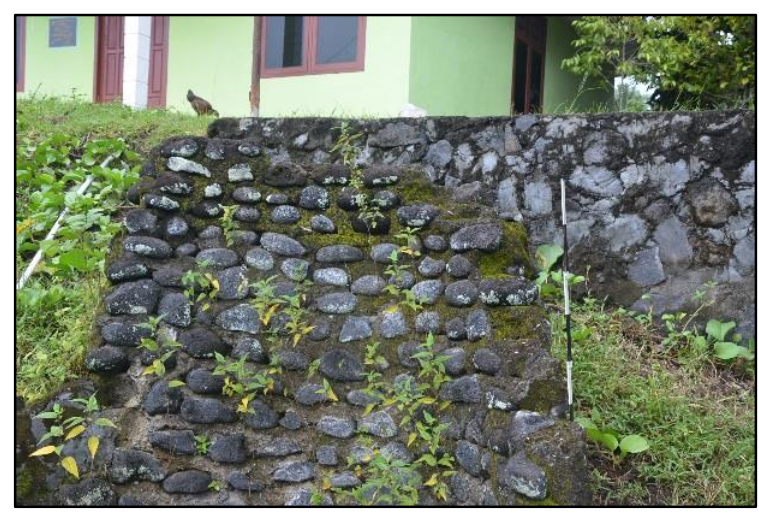

Gambar 6. Sisa-sisa pondasi Masjid Kuno Soasio, Galela

(Sumber: Tim Penelitian, 2014)

Tampak lokasi masjid tanahnya lebih tinggi di banding permukaan tanah sekitarnya. Sisa-sisa tangga tampak di bagian depan atau bagian timur lokasi masjid. Struktur bekas tangga terdiri dari spesi pasir dan batu kapur yang menyambungkan batu-batu pondasi. Sementara sumur tua terdapat di bagian depan sebelah utara masjid. Sumur tua tersebut, masih 
tampak susunan batu pembentuk dinding sumur Soa Siu sekarang merupakan ibukota kecamatan Galela. Peninggalan arkeologi di daerah ini juga sangat minim. Berdasarkan hasil survei dan wawancara, tinggalan arkeologi di permukaan tanah hanyalah bekas masjid lama Soa Siu dan makam kuno Kapitan Lahamajojo, seorang kapitang utusan Ternate yang menjadi pemimpin di wilayah Galela. Makam berbentuk sederhana, jirat susunan batu dan nisan menhir. Selain itu disamping makan tersebut, terdapat makam kuno yang spesisik, berbentuk bundar, yakni jirat susunan batu berbentuk lingkaran dan satu buah nisan batu menhir diletakkan ditengah susunan batu yang berbentuk melingkar (lingkaran). Makam berada di samping rumah penduduk, seorang keturunan dari Kapitang Lahamajojo.

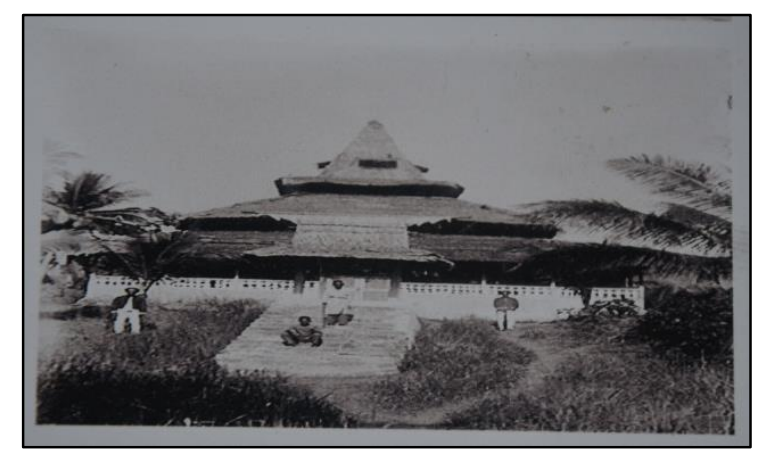

Gambar 7. Foto repro masjid kuno Soasio Galela, yang kemungkinan gambar diambil dari awal abad $20 \mathrm{M}$.

(Sumber: Foto diperoleh dari koleksi penduduk, 2014)

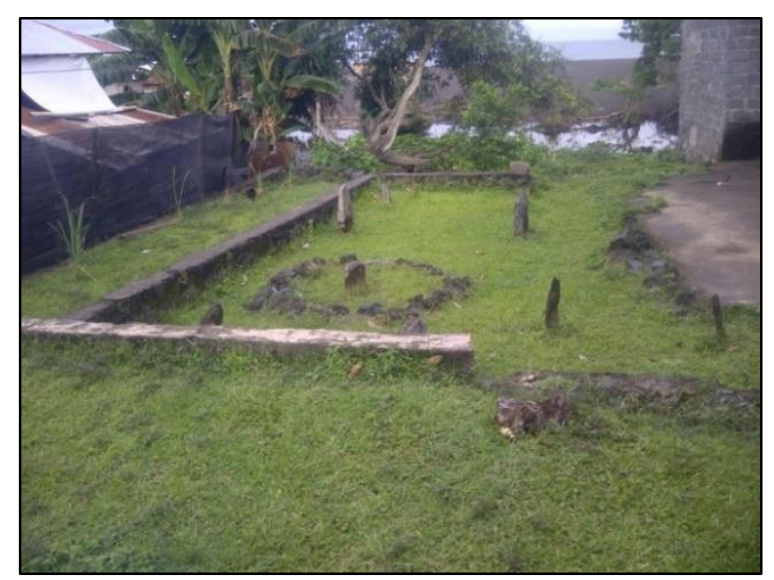

Gambar 8. Makam Kapitan Lahamajojo dan kerabat di Situs Desa Galela (Sumber: Tim Penelitian, 2014)
Mamuya, adalah sebuah desa yang pada masa lampau dianggap sebagai ibukota Kerajaan Moro (Naping, 2013: 83). Meskipun demikian dari hasil survei tidak banyak ditemukan data arkeologi di permukaan tanah. Dari hasil survei dijumpai lokasi dipinggir pantai yang berhadapan dengan pulau Morotai di sebelah utara, yang sekarang menjadi pemukiman penduduk. Dari hasil survei permukaan tanah, di lokasi tersebut banyak ditemukan pecahan keramik yang didominasi keramik yang berasal dari Dinasti Qing abad 18-19 M.

Data yang cukup signifikan di wilayah ini ditemukan di Desa Ruko yang lebih dekat dengan kota Tobelo. Di Desa Ruko, tim penelitian melakukan survei di wilayah bukit, di Daerah Aliran Sungai (DAS) Mede, dan muara sungai di sebelah baratnya. Dari tradisi tutur masyarakat Ruko, di wilayah ini pada masa lampau merupakan wilayah benteng pertahanan Portugis sebelum memindahan pusat pertahanannya di Mamuya. Di lapangan ditemukan singkapan struktur batu yang kemungkinan sebagai susunan batu benteng pertahanan tradisional.

Hasil survei di lokasi situs juga menemukan adanya lesung batu yang merupakan salah satu perkakas sehari-hari masyarakat di wilayah tersebut. Ukuran lesung batu adalah diameter atas $48 \mathrm{~cm}$ dan diameter bawah $15 \mathrm{~cm}$. Kondisi lesung batu di bagian bawah sudah berlubang, karena aus dimakan waktu, atau karena adanya tetesan air hujan terus menerus dalam waktu yang lama. Tinggi lesu batu $27 \mathrm{~cm}$ (Tim Penelitian, 2014: 43).

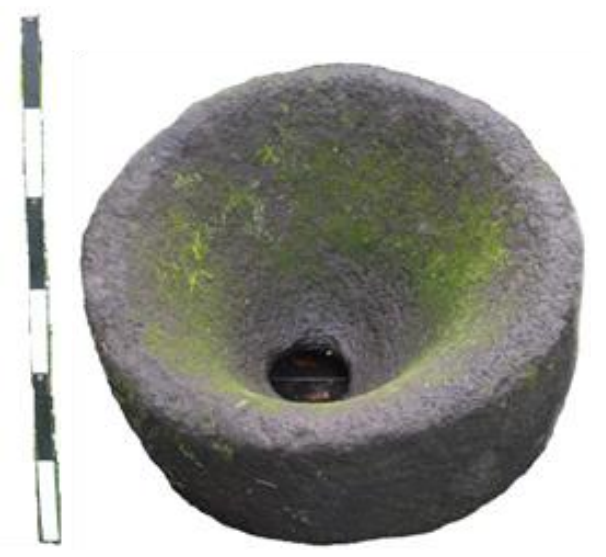

Gambar 9. Temuan lesung batu di situs Desa Ruko (Sumber: Tim Penelitian, 2014) 
Temuan lesung batu memberikan ketegasan atas peran situs dalam perkembangan pemukiman masyarakat pendukungnya pada masa lampau. Selain itu dapat memberikan gambaran tentang aktivitas penduduk, soal mengolah sumberdaya lahan, tradisi bercocok tanam dan sebagainya. Situs Ruko, dalam beberapa sumber merupakan salah satu situs kampung tua, sebuah tempat bermukim, masyarakat Ruko pada masa lampau.

Fakta ini pula menyebabkan wilayah Ruko menjadi ajang perebutan antara Ternate dan Portugis serta Belanda. Tradisi tutur menyebutkan, Ruko merupakan salah satu benteng pertahanan tradisional masyarakat pada masa lampau sebelum dikuasai Portugis. Portugis sempat membangun benteng di lokasi tersebut, namun belum selesai pengerjaannya sudah dihancurkan oleh Belanda.

Berdasarkan sumber lisan menyebutkan, pada masa itu sekitar 1557, Ruko dikuasai oleh Portugis, dijadikan sebagai pusat pemukiman, sebelum kemudian pindah di wilayah Mamuya, sebelah selatan Ruko sekarang. Pada saat survei, ditemukan struktur batu yang diduga sebagai susunan batu bekas perbentengan, yang kemungkinan menunjukkan bekas struktur benteng tradisional masyarakat Ruko sebelum dikuasai Portugis. Menyangkut keberadaan susunan batu, terdapat tradisi tutur masyarakat Ruko yang menceritakan tentang keberadaan Benteng, yang dibangun Portugis pada masa lampau.

Perlawanan Ternate terhadap Portugis dan Belanda, di wilayah pesisir Halmahera Barat, dilakukan oleh utusan Sultan, yakni Tomagola yang bergelar Kapitang Joumamongare, yang menguasai empat suku di Tobelo, sudah merapat dan menetap di Gamsungi, dan mendirikan rumah O Hibua. Sementara itu Portugis dan Belanda, masih mencari jalan menuju utara. Akhirnya Portugis yang terlebih dahulu sampai di Ruko Tanjung Selatan, sedangkan Belanda, turun di Pulau Mede. Saat itu Belanda dan Portugis terlibat persaingan dan masing-masing memerintahkan rakyat disitu untuk membangun benteng pertahanan. Diantaranya keduanya membuat kesepakatan, siapa yang terlebih dulu selesai membuat benteng, dialah yang berkuasa, baik Portugis maupun Belanda memaksa rakyat membangun benteng pada tengah malam. Portugis, membuat benteng dengan bekerja seperti biasa dan tidak menyadari bahwa saat itu,
Belanda melancarkan tipu muslihat, agar terkesan Belanda lebih dulu selesai membangun benteng. Belanda memerintahkan orang untuk membungkus Pulau Mede dengan kain putih, dan siang hari, Portugis mengira, bahwa kain putih itu adalah benteng Belanda yang dicat warna putih. Sementara karena bekerja membangun benteng seperti biasa, pada siang hari, Portugis belum menyelesaikan bangunan bentengnya. Akhirnya karena malu, Portugis meninggalkan lokasi itu (Hasil percakapan dengan Ibu Dorsilam Popa, 2014).

Selain data yang disebutkan di atas, bukti yang sekarang, wilayah Ruko merupakan wilayah dari kekuasaan Ternate, adalah adanya naskah surat keputusan tahun 1998 yang ditandantangani oleh Sultan Ternate, tentang pemberian gelar Adat Kapitang Boeng, kepada Franco Tigele Tamagola, seorang tokoh masyarakat desa Ruko. Data ini memperkuat data sejarah, bahwa sejak abad 16, yakni pada masa Sultan Baabullah, praktis wilayah Kerajaan Moro, meliputi Galela dan Tobelo, dibawah kekuasaan Ternate.

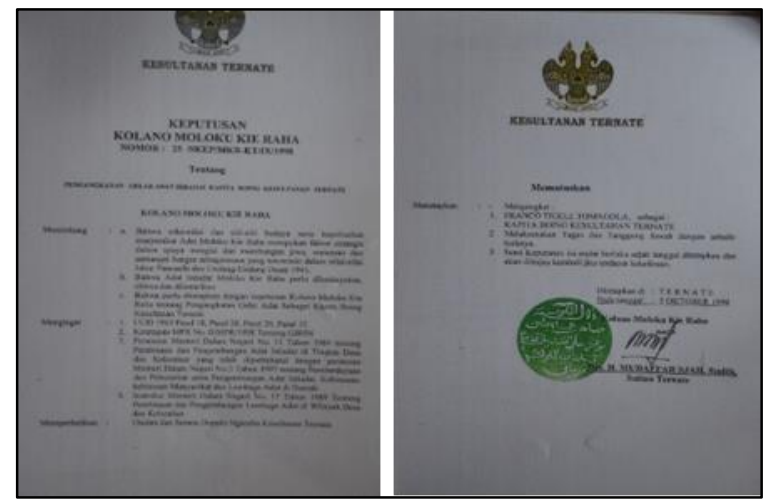

Gambar 10. Surat Keputusan dari Kolano Moluko Kie Raha Sultan Ternate, tentang penunjukkan Kapitang Boing Kesultanan Ternate, tertanggal 5 Oktober 1998

(Sumber: Tim Penelitian, 2014)

Data arkeologi berupa pemukiman kuno yang dikenal Situs Kampong Tua Kao, di Kecamatan Kao, menunjukkan pengaruh Islam yang kuat. Pada lokasi situs juga ditemukan kompleks Makam kuno masa Islam. Situs makam yang paling populer adalah Stus Makam Syekh Mansyur, yang dipercaya sebagai penyiar Islam pertama di wilayah tersebut. Selain situs makam Syekh Al Mansyur yang terletak di Desa Popon, juga terdapat kompleks makam istri 
Syekh Al Mansyur beserta kerbat yang terletak $350 \mathrm{M}$ dari makam Syekh Al Mansyur.

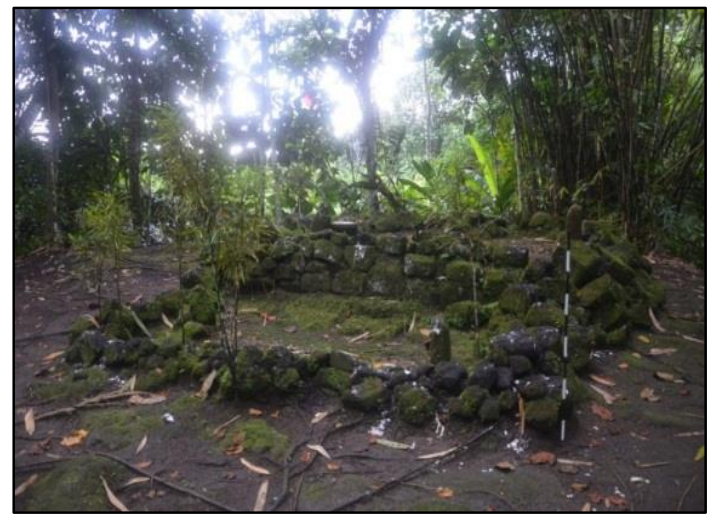

Gambar 11. Makam Syekh Mansyur dan muridnya di Bukit Gogoneng

(Sumber: Tim Penelitian, 2014)

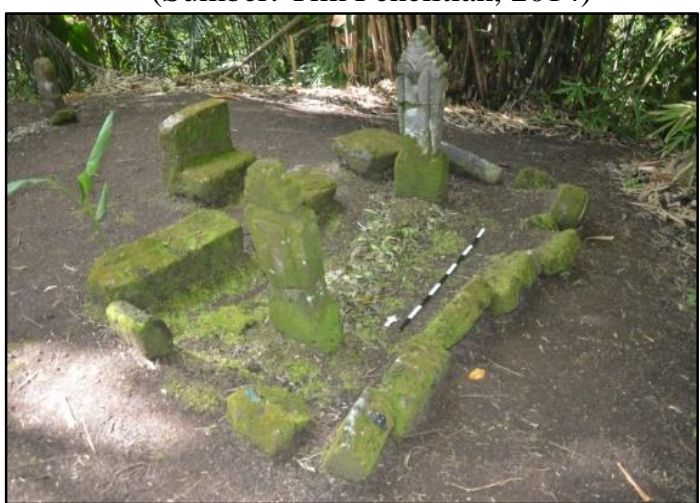

Gambar 12. Makam istri Syekh Mansyur di Gamsungi, Situs Kampung Tua Kao (Sumber: Tim Penelitian, 2014)

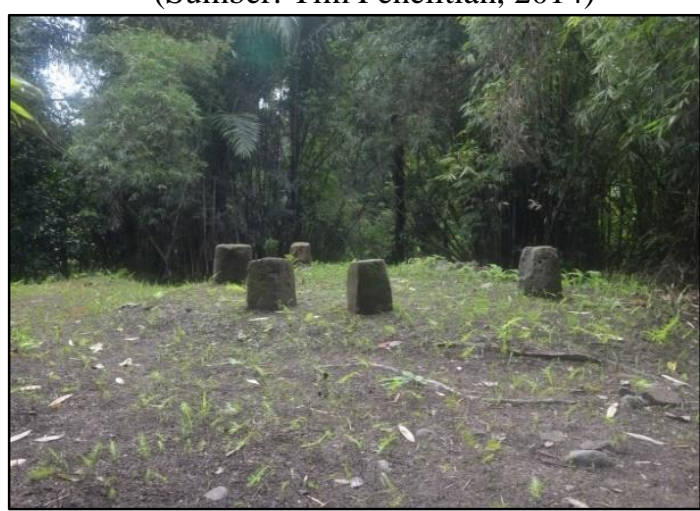

Gambar 13. Situs bekas masjid kuno yang memperlihatkan umpak-umpak bekas tiang masjid di situs Kampong Tua Kao

(Sumber: Tim Penelitian, 2014)

Pada kompleks tersebut terdapat sembilan makam, selain makam utama adalah makam Istri Syekh Al Mansyur, yakni makam kerabat atau pengikutnya. Lokasi makam, disebut masyarkat sebagai Situs Gamsungi. Selain situs makam tersebut, di seberang sungai ditemukan kompleks makam yang cukup masif yang tersebar di daerah atau di bantaran Sungai Kalak. Makam-makam tersebut tersebar di sepanjang tepian atau bantaran sungai di atas permukaan tanah yang cukup rata.

Temuan arkeologis di wilayah Kao, ini yang paling padat dan beragam dibanding dengan wilayah situs lainnya di wilayah Halhmahera Utara. Dalam tradisi tutur masyarakat setempat situs pemukiman kuno, dikenal dengan nama Situs Kampong Tua Kao, merupakan wilayah pemukiman awal ketika masuknya Islam di wilayah pesisir pantai Kao dan Halmehera Utara. Menurt tradisi setempat pada masa awal Islam masuk di wilayah ini, masyarakat masih 'tafakur' atau kondisi berdiam diri. Pada masa ini, adalah masa awal pengenalan Islam yang dibawa oleh seorang penyebar Islam bernama Syekh Al Mansyur, yang dipercaya datang dari Bagdad (masyarakat setempat menyebutnya Buqudad).

Pengertian Islam masih tafakur menurut tokoh adat setempat adalah bahwa Islam yang diajarkan merupakan ajaran sufi dan ajaran syariat yang belum lengkap atau masih sebatas pengenalan. Kata tafakkur berdiam diri, artinya masih sebatas mendengarkan ajaran dan merenung serta berdiam diri untuk mendengarkan ajaran-ajaran tentang Islam, dalam kondisi ini maka syariat Islam belum dilaksanakan sebagaimana mestinya.

Pada saat mengajarkan Islam, Syekh Al Mansyur mengangkat penduduk setempat menjadi muridnya yang sangat setia. Kesetiaan muridnya itu dibuktikan saat Syekh Al Mansyur meninggal dunia, muridnya mengubur diri di samping makam Syekh Al Mansyur, oleh karena itu di lokasi makam Syekh Al Mansyur yang dapat disaksikan sekarang yang terletak di sebuah bukit di Desa Popon, terdapat dua makam, satu makam berukuran besar adalah makam Syekh Al Mansyur, dan disampingnya makam yang lebih kecil, adalah makam muridnya, yang tidak diketahui namanya (Hasil percakapan dengan Kifli Tukan, 2014).

Berdasarkan informasi masyarakat setempat, masyarakat Kao yang sekarang bermukim di pesisir, pada masa lampau bermukim di Situs Kampong Tua Kao lama yang terletak di pinggir sungai Air Kalak, yang muaranya terletak di sebelah utara. Pada tahun 1904, penduduk Kao lama pindah ke pemukiman 
yang sekarang ditempati di pesisir pantai. Desa Kao di pesisir pantai berbatasan dengan sebelah utara dengan Kao Utara, sebelah selatan dengan Kecamatan Malifut, sebelah timur dengan Teluk kao dan sebelah barat dengan Kecamatan Kao Barat. Lokasi situs kampong lama, termasuk dalam wilayah Kecamatan Kao Barat, tepatnya 2 km sebelah barat Desa Popon.

Berkaitan dengan keberadaan kompleks Makam Syekh Mansyur dan para pengikutnya, terdapat tradisi ziarah yang berlangsung satu tahun sekali, yakni pada bulan Sya'ban (Nisyu Sya'ban), 7 (tujuh ) malam sebelum masuk bulan Ramadhan, ziarah berlangsung selama dua hari. Ritual ziarah meliputi dzikir sampai pagi, kemudian esok harinya ke makam Syekh Mansyur. Satu hari sebelumya ziarah ke makam yang disebut sebagai kubur panjang, yakni makam Ahmad Solok dari suku Aluk. Ia adalah orang pertama masuk Islam yang diajarkan Syeh Mansyur.

Secara keseluruhan, di kawasan situs pemukiman lama Kao atau Stus Kao Lama, terdiri dari beberapa kluster situs, yakni: a) Situs Makam Kuno Syekh Al Mansyur dan muridnya yang terletak di daerah bukit di Desa Popon, b) Makam istri Syekh Al Mansyur beserta pengikutnya, yang terletak $500 \mathrm{M}$ di sebelah barat makam Syekh Mansyur, atau masyarakat menyebut lokasi tersebut dengan sebutan Kampong Gamsungi, c) Situs Pemukiman Lama, di sebelah barat Situs Makam Istri Sykeh Al Mansyur dan pengikutnya yang terletak di seberang Sungai Air Kalak. Pada area lokasi situs pemukiman, selain terdapat banyak sebaran makam-makam kuno, juga situs atau lokasi bekas Masjid Kuno Kao Lama, yang ditandai adanya temuan sebaran umpak-umpak yang tertata rapi, tampak menunjukkan pola keletakan tertentu yang diduga sebagai bekas umpak tiang penyangga Masjid Kao Lama yang berjumlah 12 sesuai dengan konstruksi masjid-masjid kuno pada umumnya di Maluku (Handoko, 2013 : 44; Handoko, 2016: 145; Handoko, dalam persiapan). Situs bekas masjid kuno, menempati areal yang lebih tinggi dibanding daerah sekitar yang kemungkinan dimanfaatkan sebagai lokasi hunian.

\section{Islamisasi di Halmahera Utara: Faktor Politik dan Ekonomi}

Sejarah dan perkembangan Islamisasi di wilayah pesisir Halmahera Utara tidak bisa dipisahkan dengan wilayah kerajaan-kerajaan Islam yang berkembang di wilayah Maluku Utara yang diwakili oleh empat kerajaan besar yakni Ternate, Tidore, Bacan dan Jailolo. Hamka Naping menjelaskan meski sejak awal Halmahera Utara adalah bagian (vassal) dari Kesultanan Ternate, penguasaannya tidak secara langsung, tetapi melalui para Sangaji. Karenanya kekuasaaan terhadap wilayahwilayah ini hanya ada dalam proporsi dengan kerjasama yang mereka dapatkan dengan penguasan distrik (Sangaji). Sebagai bukti dari situasi ini dapat dilihat misalnya di abad ke 18, tepatnya 1741 , VOC mengadakan perjanjian dengan Sultan Ternate. Saat itu tidaklah cukup kalau perjanjian tersebut ditandatangai oleh sultan yang berkuasa saat itu, Amir Iskandar Zulkarnain Safiuddin Kaitjil Radja Laut, selain Gubernur Belanda (Landvoogd) dari Maluku, Maren lelievelt, yang mewakili kompeni. Selain tandatangan Sultan, juga harus ada tandatangan para sangaji dari Tobelo-tai (pedalaman Tobelo), Kao, Madoli (Madole, yaitu pedalaman Kao, Pagu (bagian dari Kau), Loloda, Tobaru, Tolofuo, Galela dan Sahoe. Inilah gambaran kekuasaan Ternate. Kesultanan memang pusat yang paling berkuasa di wilayah tersebut, namun pengaruh mereka atas Halmahera Utara dan Morotai tidaklah mutlak (Naping et.al, 2013: 207-208).

Peta sejarah politik kekuasaan Islam di Halmahera Utara pada abad 16 dipengaruhi oleh dua kekuatan utama yang berkedudukan di daratan yakni Kesultanan Jailolo dan di seberang lautan adalah Kesultanan Ternate. Perluasan pengaruh dari kedua kerajaan itu berkaitan erat dengan penyebaran Islam dan pembendungan misi Jesuit di negeri-negeri di Halmahera Utara. Setelah masyarakat Tobelo turun dari Talaga Lina ke kawasan pesisir, baik Tobelo maupun Kao mereka terkait dengan sistem pemerintahan Ternate,yang telah ada disana. Para pemimpin mereka pun mulai menggunakan gelar-gelar yang lazim digunakan oleh para Bobato di negeri-negeri pesisir. Sebagai upeti kepada kedaton, mereka dikenakan wajib untuk menyediakan tenaga dan perahu perang bagi hongi kerajaan dan upeti dalam bentuk materi. Meski demikian, pendapat lain mengatakan oleh karena jarak geografis yang jauh antara Ternate dengan Tobelo dan wilayah Halmahera Utara lainnya, sesungguhnya pengaruh kedaton Ternate terhadap wilayah itu tidaklah terlalu 
besar, hal ini berbeda dengan distrik lainnya seperti Jailolo, Sahu, Gamkonora, Loloda, selain karena wilayah-wilayah itu juga sebagai wilayah sumber makanan untuk Kedaton Ternate, sehingga frekwensi saling mengunjungi lebih besar (Naping, 2013:46).

Salah satu sumber sejarah yang ditulis (Leirissa, 1990) menyebutkan bahwa pada abad ke-16 setidaknya terdapat empat distrik yang penting di Halmahera Utara, namun pada abad ke-19 berkembang menjadi Sembilan distrik, yaitu Galela, Tobelo, Kao, Loloda, Gamkonora, Tolofuo, Tobaru, Sahu, dan Jailolo (Leirissa, 1990: 118). Dengan demikian, Kao sudah menjadi bagian kekuasaan Ternate sejak abad 16, dan hal ini sesuai dengan informasi tutur yang menyebutkan bahwa pemukiman kuno Islam di bantaran Aer Kalak, berkembang sejak abad itu. Selain itu, sumber lisan menyebutkan bahwa Ternate, menempatkan utusannya yang dikenal dengan sebutan Sangaji Kao. Data arkeologi keramik, yang berasal dari Dinasti Ming abad $16 \mathrm{M}$, dapat mengkonfirmasi data sejarah tersebut. Informasi kesejarahan yang penting menyangkut adanya temuan situs pemukiman lama Kao, di wilayah Daerah Aliran Sungai (DAS) Kao atau lebih tepatnya yang mengarah ke aliran Sungai Kala atau Sungai Jodo, bahwa pemukiman lama di bantaran sungai itu, merupakan komunitas muslim yang dapat dihubungkan dengan fakta-fakta sejarah yang berhubungan dengan wilayah Tobelo dan pesisir timur Halmahera Utara lainnya.

Sejak berpindah ke wilayah pesisir, masyarakat Tobelo mulai terkait dengan kekuasaan Ternate, yang sudah tertanam antara lain sebelumnya di Gamkonora, Loloda dan Jailolo. Orang Tobelo sejak saat itu mempunyai hubungan politik tertentu dengan penguasa negeri Gamkonora seperti halnya sebagian dari masyarakat Alifuru lainnya di jazirah utara itu. Sejak abad ke-18 Ternate mengangkat seorang penguasa (bobota) tersendiri dari salah satu keluarga dalam suku Lina yang telah beragama Islam untuk orang-orang Tobelo tersebut. Sekitar masa itu suatu kelompok dari orangorang Tobelo memisahkan diri dan berpindah ke wilayah Kao, tempat mereka juga terbagi dalam empat Hoana yaitu Boeng, Tunai, Seleruru dan Madang. Oleh Ternate mereka dianggap sebagai bagian dari kekuasaan Distrik Kao (Heuting, 1905 dalam Naping, 2013:42). Informasi ini kiranya dapat dihubungkan dengan temuan arkeologis berupa pemukiman lama Kao di bantaran sungai Aer Jodo dan Aer Kala, di pedalaman Kao sekarang. Hal ini karena mengingat sumber sejarah juga menyebut adanya pemukiman orang-orang Tobelo yang berpindah ke wilayah Kao, yang juga disebutkan berjumlah sekitar 403 jiwa, meskipun pada awal kepindahan tersebut, sesungguhnya belum diperoleh informasi yang pasti. Kemungkinan pemukiman awal orang-orang Tobelo yang berpindah ke wilayah Kao, dapat dihubungkan dengan situs pemukiman kuno Kao di Aer Kalak tersebut.

Kedatangan Islam menimbulkan pengaruh ekonomi yang cukup besar terhadap pulau-pulau di wilayah Maluku Utara, termasuk wilayah Halmahera Utara. Ada banyak hubungan antara penyebaran Islam dan perkembangan perdagangan internasional. Terlihat bagaimana perkembangan pos-pos perdagangan selain Ternate juga di Tobelo, Galela (termasuk Pune), dan Kao. Dalam masing-masing wilayah vassal atau sangadji muncul suatu komunitas perdagangan yang berhubungan langsung dengan istana. Komunitas ini mungkin ada di lebih dari satu desa pantai di sebuah daerah vassal. Sumber lain tentang perjalanan para pelaut China pada abad 15, lebih spesisifik menyebutkan daerah Galela di Halmahera Utara sebagai salah satu tujuan pelayaran dari China. Rutenya dari Amoy melalui Mindoro ke Halmahera. Dari Mindoro, kapal China menuju bagian timur Mandanau kemudian ke kepulauan talaud, selanjutnya ke Chih-Lo-Li (Galela di Halmahera), salah satu daerah di Mei-Lo-chu (Maluku). Dalam catatan navigasi itu terdapat sejumlah nama daerah di Maluku utara, seperti 'Ch'ien-tzu- Informasi terakhir menjelaskan antara Galela dan Maluku, keduanya dapat dipahami sebagai Maluku Utara. Menyangkut peran Kerajaan Moro, meskipun dalam sejarah wilayah ini cukup penting, namun hasil survei di Desa Mamuya, belum memperoleh data arkeologi yang memperkuat babakan sejarah tentang peran wilayah ini dalam sejarah lokal. Kota penting kerajaan Moro adalah Mamuya. Selain itu kota penting lainnya adalah Sugala, Pune (Galela), Tolo, Cawa, Samafo (Tobelo), Sakita, Mira, Cio, dan Rao. Penduduknya menganut Islam, sebagian Kristen dan agama lokal. Pada zaman Portugis, kerajaan ini diperintah oleh seorang raja bernama Tioliza. Secara etnografis, kerajaan ini terdiri dari etnis 
Tobelo dan Galela. Mereka berasal dari kelompok hoana (kampung, negeri) Morodina, Morodai, Lina, Gura, Mumulati dan Huboto (Amal 2010: 129, Naping, 2013:78 ).

Hasil survei yang penting ditemukan di situs Desa Ruko dengan lanskap perbukitan landai yang diapit sungai dan laut, serta permukaan tanah situs yang rata dengan kondisi tanah yang subur, tidak menutup kemungkinan desa ini cukup penting pada masa lampau. Informasi penduduk yang menyebutkan bahwa pada masa lampau di wilayah ini terdapat benteng pertahanan dalam upaya melawan Portugis, dapat dikonfirmasi dengan data lapangan, yakni adanya temuan struktur batu yang diduga sisa-sisa reruntuhan benteng tradisional.

Selain itu temuan penting lainnya adalah adanya lesung batu yang dapat mengkonfirmasi catatan-catatan sejarah meskipun disertai mitos soal adanya aktivitas pertanian ataupun pengolahan padi ladang di wilayah tersebut. Pada lokasi sekitar tempat permukiman Tolo berada, diantara penduduk dikenal sebagai kota Tolo. Menurut kisah mereka sering mendengar aktivitas menumbuk padi pada malam hari dan sering tampak bahwa seseorang di daerah ini menemukan sebuah batu yang cocok difungsikan sebgai lesung dan jika orang membawanya ke kampung, keesokan harinya ditemukan bahwa batu itu telah kembali ke tempatnya ditemukan, diduga dibawa oleh orang Tobelo. Pada lokasi itu juga ditemukan berbagai potongan keramik di benteng ini. Benteng ini berdiri di tepi aliran kiri dengan muara Sungai Mede. Setelah letusan gunung Dukono, daerah antara Sungai Mede dan Gunung Mamuya ditaburi dengan material gunung api yang membuat sebagian lahannya tidak subur (Naping, 2013: 202).

Fakta arkeologi maupun catatan sejarah dapat menjelaskan bahwa wilayah Halmahera Utara memiliki peran penting sebagai penyedia bahan makanan pokok, padi ladang dan sagu bagi suplai kebutuhan Kesultanan Ternate maupun daerah sekitarnya. Fakta tentang sumber ekonomi itu misalnya ditunjukkan adanya pengelolaan sagu dan tradisi padi ladang yang masih bertahan hingga kini, diantaranya di wilayah Kecamatan Kao hingga sekarang (Tim Penelitian, 2014: 71; Handoko, et.al., 2016: 127). Terdapat sumber informasi yang menjelaskan bahwa pada masa lampau, Moro merupakan penghasil beras terbesar di Maluku, karenanya menjadi gudang pangan seperti beras, ikan, sagu, daging yang menyuplai kebutuhan ke Ternate (Amal, 2010: 208).

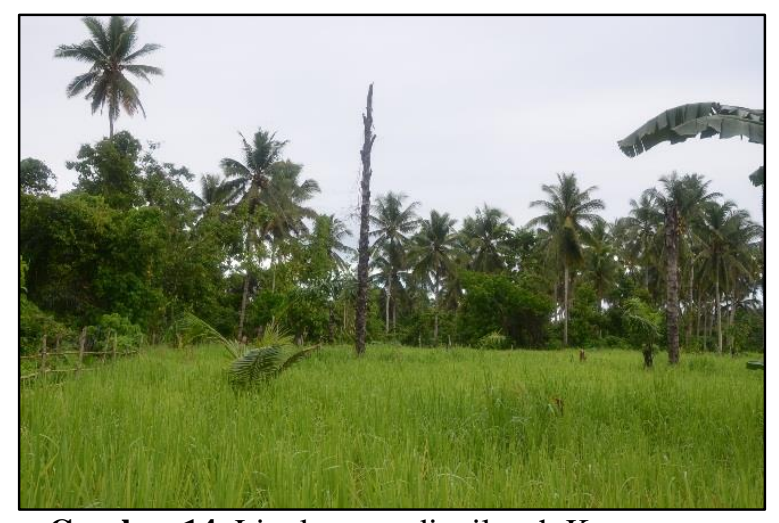

Gambar 14. Lingkungan di wilayah Kecamatan

Kao, terdapat areal padi ladang. Tradisi padi ladang sudah berkembang sejak masa pertumbuhan kerajaan-kerajaan Islam di Maluku Utara (Sumber: Tim Penelitian, 2014)

\section{KESIMPULAN}

Hasil penelitian menunjukkan bahwa kawasan pesisir utara Pulau Halmahera, potensial untuk menjelaskan sejarah Islamisasi, perdagangan dan perkembangannya masa kemudian. Data arkeologi setidaknya dapat mendukung informasi sejarah yang selama ini sudah banyak diungkap. Berdasarkan temuan data arkeologi dapat disimpulkan beberapa hal antara lain: pertama, kawasan pesisir utara Pulau Halmahera merupakan wilayah pinggiran kekuasaan Kesultanan Ternate yang cukup penting posisinya dalam rangka mendukung eksistensi Ternate sebagai pusat peradaban Islam. Kedua, kisaran abad 16 merupakan periode yang sangat penting bagi wilayah itu dalam konteks perkembangan niaga dan proses penyebaran Islam. Ketiga, wilayah Halmahera utara, sebagai wilayah dari kekuasaan Ternate, merupakan wilayah jejaring niaga dalam perkembangan Islam dan perkembangan ekonomi politik Kesultanan Ternate. Keempat, terbentuknya kantung-kantung pemukiman Islam pada masa lampau baik di wilayah pesisir maupun pedalaman, sebagai bentuk perkembangan Islam di wilayah itu, dan beberapa diantaranya masih dapat ditemukan seperti di wilayah Kecamatan Kao.

Pada wilayah-wilayah situs potensial yang diperoleh berdasarkan survei, kiranya perlu 
ditindaklanjuti melalui penelitian yang lebih sistematis, misalnya melalui ekskavasi untuk memperoleh gambaran tentang aktivitas penduduk dan perkembangan pemukiman di wilayah-wilayah situs potensial tersebut. Selain itu perlunya sosialisasi di sekolah dan pemerintah setempat, tentang nilai sejarah budaya di wilayah-wilayah penelitian. Situs pemukiman kuno Kao di Daerah Aliran Sungai (DAS) Akejodo di Kecamatan Kao, perlu diletarikan dan dikelola dengan sistem manjamen lebih baik, karena lokasi situs potensial untuk obyek studi lapangan dan wisata religi atau wisata ziarah Melalui pengelolaan situs yang lebih terpadu, diharapkan dapat menjadi asset pembangunan daerah bidang pariwisata, kebudayaan dan juga pendidikan.

\section{Ucapan Terima Kasih}

Penulis mengucapkan terima kasih kepada seluruh pihak-pihak yang telah membantu selama penelitian berlangsung hingga dipublikasikannya artikel ilmiah ini. Terima kasih kepada saudara Cheviano Alputila yang banyak membantu melakukan analisis kronologi keramik. Kepada saudara Muhammad Al Mujabuddawat juga diucapkan terima kasih atas bantuannya menyiapkan peta dan deskripsi data lainnya.

$$
* * * * *
$$

\section{DAFTAR PUSTAKA}

Amal, A. M. (2010). Kepulauan Rempah-rempah Perjalalanan Sejarah Maluku Utara 12501950. Jakarta: Kepustakaan Populer Gramedia.

Ambary, H. M. (1998). Menemukan Peradaban Jejak Arkeologis Historis Islam di Indonesia. Jakarta: Logos. Wacana Ilmu.

Andaya, Leonard, Y. (2015). Dunia Maluku. Indonesia Timur Pada Zaman Modern Awal. Yogyakarta: Penerbit Ombak.

Deetz, James. (1967). Invitation to Archeology. New York: The Natural History Press.

Fagan, Brian, M. (1985). In the Beginning: An Introduction to Archaeology. Toronto: Little, Brown and Company.

Handoko, W. (2010). Konversi Islam dan Determinasi Kekuasaan. Studi Arkeologi di Kawasan Teluk Waru, Kabupaten Seram Bagian
Timur, Provinsi Maluku. Kapata Arkeologi, 6(10), 1-18.

Handoko, W (2008) Ekspansi dan Rivalitas Kekuasaan Islam: Pengaruhnya di Wilayah Siri Sori Islam, Pulau Saparua, Maluku Tengah. Kapata Arkeologi 5(8), 1-22.

Handoko, W (2009). Dinamika Budaya Islam di Wilayah Maluku Bagian Selatan. Kapata Arkeologi, 5(9), 14-31.

Handoko, W. (2013). Karakteristik Arsitektur Masjid di Maluku. Amerta, 31(1), 1-80.

Handoko, W. (2015). Tata Kota Islam Ternate. Tinjauan Morfologi dan Kosmologi. Kapata Arkeologi, 11(2), 123-138.

Handoko, W. (2016). Islam Negeri Kaitetu: Relasi Islam, Adat dan Pemerintahan Lokal. Universitas Pattimura.

Handoko, W. et.al. (2016). Laporan penelitian: Menguak Identitas Asal Usul Komunitas, Sejarah dan Peradaban Islam di Halmahera Utara. Ambon: Balai Arkeologi Maluku.

Hanna, W., A., \& Alwi, Des. (1996). Ternate dan Tidore, Masa Lalu Penuh Gejolak. Jakarta: Sinar Harapan.

Insoll, T. (2001). Introduction. The Archaeology of World Religion. In Insoll, T. (Ed.), Archaeology and World Religion. London: Routledge.

Lape, P. V. (2000a). Contact and colonialism in the Banda Islands, Maluku, Indonesia. Bulletin of the Indo-Pacific Prehistory Association, 20, 4855.

Lape, P. V. (2000b). Contact and Conflict in the Banda Islands, Eastern Indonesia, 11th-17th Centuries. Ph.D. Brown University.

Lape, P. V. (2000c). Political Dynamics and Religious Change in the Late Pre-colonial Banda Islands, Eastern Indonesia. World Archaeology, 32(1), 138-155.

Lape, P. V. (2005). Archaeological Approaches to the Study of Islam in Island Southeast Asia. Focus on Islam IV. Antiquity, 79, 829-836.

Leirissa, R. Z. (1990). Masyarakat Halmahera dan Raja Jailolo. Studi tentang Sejarah Masyarakat Halmahera Utara. Universitas Indonesia.

Leirissa, R. Z. (2001). Jalur Sutera: Integrasi LautDarat dan Ternate sebagai Bandar di Jalur Sutera. In M. J. Abdulrahman, dkk, (Ed.), Ternate: Bandar Jalur Sutera. Ternate: LinTas (Lembaga Informasi dan Transformasi Sosial).

Naping, Hamka, dkk, (2013). Halmahera Utara, Sejarah Perkembangan Peradaban di Bumi Hibua Lamo. Makassar: Fakultas Sosial Politik Univeritas Hasanuddin, Pemerintah Kabupaten Halmahera Utara dan Yayasan Bina Generasi.

Reid, Anthony. (2011). Asia Tenggara dalam Kurun Niaga 1450-1680. Jilid 1: Tanah Di Bawah Angin. Jakarta: Yayasan Pustaka Obor Indonesia. 
Ricklefs, M. C. (2008). Sejarah Indonesia Modern 1200-2004. Jakarta: PT. Serambi Ilmu Semesta.

Tim Penelitian. (2014). Laporan penelitian: Arkeologi Islam di Wilayah Pesisir Timur Kabupaten Halmahera Utara. Ambon: Balai Arkeologi Maluku. Tidak terbit. 